\title{
Effect of domestic grey water reuse for irrigation on soil physical and chemical characteristics and tomatoes growth.
}

\author{
GuIllaume NyAGATARE $^{1 *}$, Christian SHINGIRO $^{1, *}$, Claire NYIRANZIRINGIRIMANA $^{1}$ \\ School of Agriculture Engineering, College of Agriculture, Animal Sciences and Veterinary \\ Medicine, University of Rwanda, Nyagatare, Rwanda \\ *Correspondence details: shichriss2020@gmail.com
}

\begin{abstract}
This study aimed at determining the effect of laundry grey water on the growth of tomatoes and physical and chemical properties of a sandy loam Ustox located in the Eastern province of Rwanda, Kayonza district, Mwiri sector. The experimental design consisted of plots planted with tomatoes (Lepersicon Esculantum) in a randomized complete block design with three replications and four treatments. Treatment 1: Tomatoes irrigated with pure grey water; Treatment 2: Tomatoes irrigated with a mixture of tap water and grey water at 1:1 ratio; Treatment 3: Alternation of grey water and tap water in a consecutive manner; and Treatment 4: only tap water serving as a control. Results showed that the following soil chemical parameters were significantly increased with grey water application: $\mathrm{pH}, \mathrm{EC}, \mathrm{Av} \mathrm{P}$, $\mathrm{Na}$ and SAR. Conversely, soil concentration in $\mathrm{Mg}$ and $\mathrm{Ca}$ significantly decreased with increase in grey water application. Apart from soil bulk density, other measured physical properties such as soil hydraulic conductivity, aggregate stability and porosity were significantly reduced with grey water application. The highest values for soil hydraulic conductivity, aggregate stability and porosity were found for soil irrigated with tap water which ranged between 1.01 to 2.1 times higher than that of grey water, mixed or alternated with tap water. The alternate application of grey water and tap water did not significantly affect the stem height and weight of tomatoes. We concluded that the absence of growth effect of application of grey water was due to low concentration in essential plant nutrients in grey water, and induced adverse effects on soil chemical, physical, and biological properties. However, alternate application of grey water and tap water preserved approximately the same soil physico-chemical characteristics as with application of tap water. Thus, among the irrigation treatments involving grey water, the latter should be considered as the most environmentally friendly. We propose combination of grey water with various forms of composts as the one of the most promising investigations on the reuse of grey water in irrigation.
\end{abstract}

Keywords: $p H, E C, S A R$, nutrients' concentration, hydraulic conductivity, tomato growth.

\section{Introduction}

Most of the world's food supply comes from agriculture which depends on water, whether from rain, irrigation or a combination of the two (Pescod, 1992). Agricultural water reuse practices vary significantly around the world, ranging from the use of untreated wastewater in regions where wastewater treatment is limited, to the use of 
highly treated recycled water in the more developed regions. In either case, both food and non-food crops are commonly irrigated. Across all contexts, water scarcity is the common motivation for agricultural reuse (Sheikh et al., 2018). Rwanda, like other countries in the world, is experiencing the effects of climate change manifested through variability and irregularity in rainfall patterns, thus, increasing competition for water resources in allocation, access and management. Agriculture which is the backbone and key component of Rwanda's economy is constantly competing with domestic, industrial, and environmental uses for a scarce water supply (World Bank Group, 2021). Yet water supply for small-scale farmers and pastoralists, who constitute the major work force in Rwandan agriculture, is an imperative toward achieving food security (Food and Agriculture Organization, 2019). Accelerating changes in land use, urbanisation, and industrialisation are aggravating competition for a scare resource. Devising more effective methods of water management is therefore increasingly imposing itself as a civilisational emergency for Rwanda, and indeed for the whole planet. The treatment and reuse of wastewater is one of the best options for water conservation available to communities located in arid and semi-arid regions. The potential for wastewater reuse is not only limited to large-scale projects supplied by community wastewater treatment facilities but is also available to individual homeowners (World Health Organization, 2006b). In dry seasons of Rwanda, agriculture is only possible trough irrigation practice. The irrigation water for extensive land or small-scale farming in marshland comes from surface water such as rivers and lakes. However, irrigation of hillside rural households' vegetable/kitchen gardens, which constitute important complements to healthy nutrition and food security in Rwanda, can hardly rely on surface water due to insufficient uphill water redistribution capacity. Thus, uphill the risk of dry-seasons starvation is real. Nonetheless, risk-averse, and household-chores-bound female household members are reluctant to irrigate their land with grey water, fearing harm to their soil, crops, and household.

Yet, generally in Rwanda bathing and laundry activities produce each approximately $10 \mathrm{~L}$ of grey water daily per person (Matto \& Jainer, 2019). In that context, a family of five persons produces approximately $100 \mathrm{~L}$ of grey water daily which could be equal to $3 \mathrm{~m}^{3}$ per month per household and $36 \mathrm{~m}^{3}$ per annum per household. And this does not include grey water produced in schools and universities, prisons, hotels, and many places receiving many people (Matto \& Jainer, 2019; Boulware, n.d.). With grey water recycling, it is possible to reduce the amounts of freshwater consumption as well as wastewater production, in addition to reducing water bills. Unlike rainwater harvesting, grey water recycling is not dependent on season or variability of rainfall and as such is a continuous and a reliable water resource. Grey water has a relatively low nutrient and pathogenic content and therefore it can be easily treated to a high quality using simple technologies (Erwin, 2005). If the grey water is used as an additional water source, an increased supply for irrigation water can be ensured, which will in turn lead to an increase in agricultural productivity and contribute to food security.

However, there are several problems related to reuse of untreated grey water. In fact, laundry grey water consists of an aqueous solution of suspended solids (dirt and lint), organic material, oil, grease, and sodium, nitrates and phosphates from detergent (Eriksson et al., 2002). The risk associated with careless use of grey water in irrigation includes soil pollution and degradation through clogging, dispersion and salinization; water bodies' eutrophication and pollution and spreading of diseases due to the exposure to micro-organisms in the water (World Health Organization, 2006a).

Therefore, reused grey water must also be of satisfactory bio-physico-chemical quality. Safe reuse of grey water implies understanding the risks and benefits associated with grey water reuse and the development of local low-cost technologies for the 
recycling and mitigation of the risks of, and amplification of the benefits of, grey water reuse for the benefit of low-income rural communities.

The overall objective of this study was therefore to contribute to a systematic investigation into ways to promote grey water reuse in Rwandan agriculture. Results were expected to strengthen the body of evidence needed to develop a safe scheme for grey water recycling and reuse in Rwanda.

The specific objective of this study was to compare the effect of three different grey water-reuse treatments (laundry grey water (T1), grey water mixed with tap water at 1:1 ratio (T2), alternation of grey water and tap water (T3) with tap water only as a control (T0), on:

Some selected physical properties: hydraulic conductivity, aggregate stability, porosity, and bulk density; and some chemical properties: $\mathrm{pH}$, Electrical Conductivity (EC), Sodium Adsorption Ration (SAR) and nutrients concentrations of a sandy loam Ustox (USDA Soil taxonomy) located in the Eastern province of Rwanda, Kayonza district, Mwiri sector.

The yield of tomatoes (Lycopersicon Esculentum) grown in the same location and soil as indicated above.

\section{Materials and Methods.}

\section{Study Area}

This research was conducted in the Eastern province of Rwanda, Kayonza district precisely in Mwiri sector (coordinates: latitude $-1.9018^{\circ}$ and longitude $30.507^{\circ}$ ) with the altitude varying between 1400 and $1600 \mathrm{~m}$ above sea level. The climate is classified as tropical savanna characterized by two rainy seasons, the longest (duration of rain events) and most intense centred around March - May, and the shortest around October to December; and two dry seasons, the longest around June - September, and the shortest around January - February. The temperature lies between $18^{\circ} \mathrm{C}$ and $26^{\circ} \mathrm{C}$ with average annual temperature and rainfall of $19.7^{\circ} \mathrm{C}$ and $898 \mathrm{~mm}$ respectively (Kayonza District, n.d.). The soil in Mwiri sector was a highly weathered sandy loam Ustox with uniform texture, high amounts of $\mathrm{Fe}$ and $\mathrm{Al}$ oxides and low Cation Exchange Capacity. 


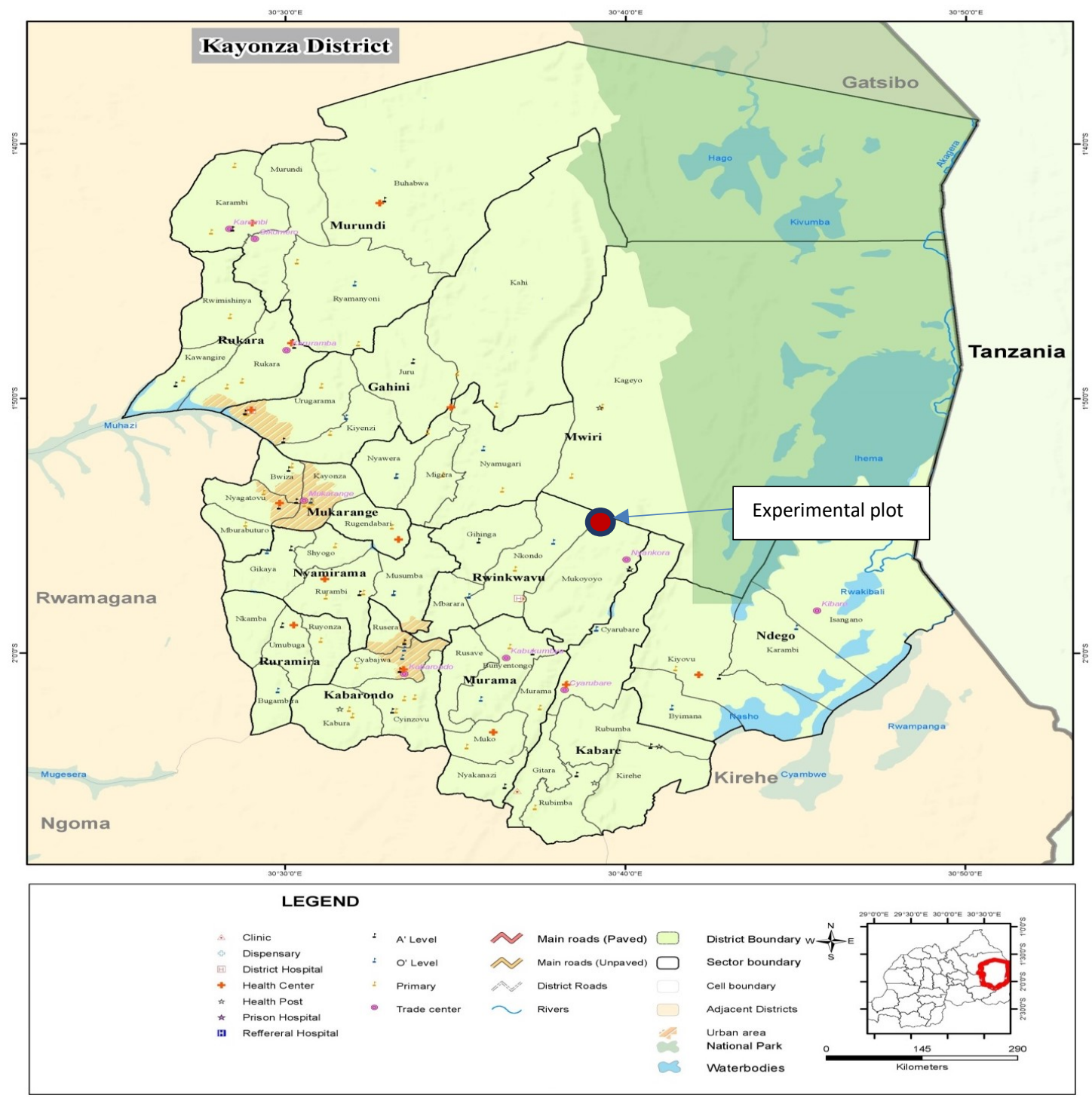

Figure 1. Location of Mwiri sector, Kayonza District (File: Kayonza district map. Source: Wikimedia).

\section{Experiment Design}

The experiments design consisted of tomato crops subjected to four irrigation treatments and three replications in randomized complete block design. Treatment 1: Pure grey water, Treatment 2: Mixture of grey water and tap water at 1:1 ratio, Treatment 3: Alternate application of grey water and tap water in consecutive patterns, and Treatment 0 : tap water which served as a control. The size of each experimental plot was $4 \times 4 \mathrm{~m}^{2}$. Plots were spaced by $1 \mathrm{~m}$ and replications were spaced by $3 \mathrm{~m}$. Irrigation treatments were applied two times a day using watering can. The irrigation was done by applying $5 \mathrm{~L}$ for each treatment (i.e., $5 \mathrm{~L}$ of grey water or $5 \mathrm{~L}$ of tap water or $5 \mathrm{~L}$ of their mixture) at $10 \mathrm{~cm}$ distance from the stem of the plant. Grey water was collected from laundry activities of the researcher's family; tap water was collected in taps distributing water treated by Rwanda Water and Sanitation Corporation. 


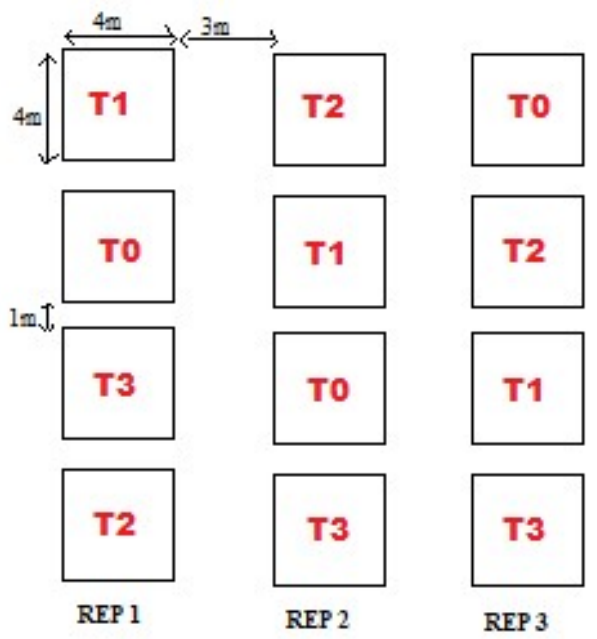

Figure 2. Experimental design layout. ${ }^{*}$ T0: soil irrigated with tap water T1: Soil irrigated with pure grey water; T2: Soil irrigated with grey water mixed with tap water; T3: Soil irrigated with an alternation of grey water and tap water.

\section{Test Crop}

Tomato (Lycopersicon Esculentum) was used to assess plant responsiveness to irrigation with grey water. The local fertilizer recommendation per hectare was $120 \mathrm{~kg}$ of $\mathrm{N}, 50 \mathrm{~kg}$ of $\mathrm{P}\left(\mathrm{P}_{2} \mathrm{O}_{5}\right)$ and $50 \mathrm{~kg}$ of $\mathrm{K}\left(\mathrm{K}_{2} \mathrm{O}\right)($ IFDC, 2014) Tomatoes were transplanted to the experimental plots two weeks after seeding from the nearby nursery and all plots were mulched with grass to reduce the evaporation and weeds growth. Irrigation water was first applied one week after the transplantation of tomato seedlings. Tomatoes were harvested two weeks after the last irrigation application, i.e., 85 days after seedlings transplantation. No additional nutrients or pesticides were applied. Tomatoes growth was measured on four selected trees per plot every week after three weeks of seedling transplantation. Tomatoes were planted spaced $60 \mathrm{~cm}$ between plants and $1 \mathrm{~m}$ between rows making 18 tomato plants/plot.

\section{Sampling, Data Collection and Analysis Methods}

For each experimental plot, soil samples were collected using an auger and core samplers at a depth of $30 \mathrm{~cm}$. A total number of 36 samples were taken i.e., one round of 12 samples at the beginning, one in the middle and one at the end of the experiment. Grey water and tap water samples were collected in $0.5 \mathrm{~L}$ plastic bottles and were kept in the fridge at $4^{\circ} \mathrm{C}$ during the analysis. The soil physical parameters measured included soil texture measured using hydrometer method, soil bulk density and porosity measured using gravimetric method. Aggregate stability was measured using wet sieving methods and saturated soil hydraulic conductivity was measured using holes method (Bandyopadhyay et al., 2012). The soil and water electrical conductivity and $\mathrm{pH}$ were measured using $\mathrm{EC}$ meter pH meter respectively (Okalebo, 2002). Total N concentrations of in soil, grey water, and tap water were measured using Kjeldhal method; available P in soil, grey water, and tap water was measured using Mehlich method; the concentrations of $\mathrm{Ca}, \mathrm{Mg}, \mathrm{Na}$ were determined using Flame atomic absorption spectrometry (AAS) and SAR was calculated as

$$
\left[\mathrm{Na}^{+}\right] /\left[\frac{\left[\mathrm{Ca}^{2+}+\mathrm{Mg}^{2+}\right]}{2}\right]^{1 / 2} \quad(\text { Okalebo, 2002). }
$$


The agronomic parameters measured included stem height and leaf diameter, both measured using a measuring tape, and tomato weight measured using an electronic balance. Data collected from this experiment was subjected to Analysis of variance (ANOVA) using Genstat discovery edition 13. Means were separated using Tukey test with an individual simultaneous confidence interval at $5 \%$ of significance level.

\section{Results and Discussions}

\section{Initial Soil and Water Characterizations}

The initials soil texture was found to be sandy loam with aggregate stability of $61 \%$, hydraulic conductivity of $1.22 \mathrm{~cm} / \mathrm{h}$, bulk density of $1.2 \mathrm{~g} / \mathrm{cm}^{3}$ and porosity of $49.2 \%$. The comparison of initial soil and water characteristics showed that the $\mathrm{pH}$ of soil (6.7) was lower to that of initial grey water (9.5) and grey water mixed with tap water (9.0). The EC of soil $(103.8 \mu / \mathrm{cm})$ was lower to that of initial grey water $(137.2 \mu / \mathrm{cm})$ which was also 1.3 and 346 times higher than that of grey water mixed with tap water $(77.0 \mu / \mathrm{cm})$ and tap water alone $(0.3 \mu / \mathrm{cm})$ respectively. Pre experiment soil (see table 1) had lower concentration in $\mathrm{Ca}(33.9 \mathrm{mg} / \mathrm{kg}), \mathrm{Na}(0.878 \mathrm{mg} / \mathrm{kg})$, and available $\mathrm{P}(0.505 \mathrm{mg} / \mathrm{kg})$ as well as a lower SAR (0.01) than all forms of irrigation treatments, i.e., grey water, grey water mixed with tap water and tap water alone (Table 2). There was no observed significant difference in Total Nitrogen in each of the initial grey water, tap water and their mixture (Table 2). However, a statistically significant difference was observed between treatments for the rest of the initial measured treatments. Initial grey water was found to have the highest $\mathrm{pH}$ (9.5) compare the initial $\mathrm{pH}$ of tap water (6.7) and tap water mixture with grey water (9.0). The initial EC $(137.2 \mu \mathrm{s} / \mathrm{cm}), \mathrm{Na}(15.32 \mathrm{mg} / \mathrm{L})$, Av P $(4.05 \mathrm{mg} / \mathrm{L})$ and SAR (2.49) of pure grey water were approximately $45,3,33$ and 4 times higher to those of tap water. Tap water on its hand was found to have the highest $\mathrm{Ca}$ and $\mathrm{Mg}$ concentrations, approximately 2.5 and 1.3 times higher to those of grey water.

Table 1. Initial soil physical and chemical characteristics

\begin{tabular}{llll}
\hline CHEMICAL PROPERTIES & & PHYSICAL PROPERTIES \\
\hline PARAMETERS & VALUES & PARAMETERS & VALUES \\
\hline $\mathrm{Ca}(\mathrm{mg} / \mathrm{kg})$ & 33.900 & \% Sand & 72.67 \\
$\mathrm{Mg}(\mathrm{mg} / \mathrm{kg})$ & 51.235 & \% Clay & 19.33 \\
$\mathrm{Na}(\mathrm{mg} / \mathrm{kg})$ & 0.878 & \% Silt & 8 \\
$\mathrm{SAR}$ & 0.01 & Textural class & Sandy loam \\
$\mathrm{pH}$ & 6.7 & Soil aggregate stability $\%$ & 61 \\
Total N $(\%)$ & 0.01 & Hydraulic conductivity $(\mathrm{cm} / \mathrm{h})$ & 1.22 \\
Available P $(\mathrm{mg} / \mathrm{kg})$ & 0.505 & Bulk density $\left(\mathrm{g} / \mathrm{cm}^{3}\right)$ & 1.2 \\
EC $(\mu / \mathrm{cm})$ & 103.8 & Porosity $(\%)$ & 49.2 \\
\hline
\end{tabular}


Table 2. Initial grey water and tap water chemical characteristics

\begin{tabular}{|c|c|c|c|c|c|c|c|c|}
\hline $\begin{array}{l}\text { TREA } \\
\mathrm{T}\end{array}$ & $\mathrm{PH}$ & $\begin{array}{l}\mathrm{EC} \\
(\mu \mathrm{S} / \mathrm{CM})\end{array}$ & $\mathrm{NA}(\mathrm{MG} / \mathrm{L})$ & MG(MG/L) & $\begin{array}{l}\text { TOT } \quad \mathrm{N} \\
(\%)\end{array}$ & $\begin{array}{l}\mathrm{AV} \\
\mathrm{P}(\mathrm{MG} / \mathrm{L})\end{array}$ & $\mathrm{CA}(\mathrm{MG} / \mathrm{L})$ & SAR \\
\hline T0 & $6.7 \pm 034 b$ & $3 \pm 0.13 \mathrm{c}$ & $5.35 \pm 0.02 \mathrm{~b}$ & $32.33 \pm 1.15 \mathrm{a}$ & $\begin{array}{l}0.01 \pm 0.00 \\
5\end{array}$ & $\begin{array}{l}0.122 \pm 0.31 \\
\mathrm{~b}\end{array}$ & $\begin{array}{l}127.78 \pm 0.32 \\
\text { a }\end{array}$ & $0.59 \pm 0.33 \mathrm{c}$ \\
\hline $\mathrm{T} 1$ & $9.5 \pm 004 \mathrm{a}$ & $\begin{array}{l}137.2 \pm 0.05 \\
\text { a }\end{array}$ & $\begin{array}{l}15.32 \pm 0.04 \\
\text { a }\end{array}$ & $\begin{array}{l}25.00 \pm 0.04 \\
\text { b }\end{array}$ & $\begin{array}{l}0.01 \pm 0.00 \\
3\end{array}$ & $4.05 \pm 0.37 \mathrm{a}$ & $50.37 \pm 0.74 \mathrm{c}$ & $2.49 \pm 0.19 \mathrm{a}$ \\
\hline $\mathrm{T} 2$ & $\begin{array}{l}9.0 \pm 0.01 \\
\mathrm{a}\end{array}$ & $77.0 \pm 0.51 \mathrm{~b}$ & $\begin{array}{l}14.33 \pm 0.03 \\
\text { a }\end{array}$ & $\begin{array}{l}24.94 \pm 0.03 \\
b\end{array}$ & $\begin{array}{l}0.01 \pm 0.00 \\
1\end{array}$ & $3.57 \pm 0.32 \mathrm{a}$ & $91.33 \pm 0.58 b$ & $\begin{array}{l}1.87 \pm 0.26 \\
b\end{array}$ \\
\hline
\end{tabular}

Mean value \pm Standard deviation (SD); values in column with the different letters are significantly different $(p \leq 0.05)$. $p H(p=0.008), E C(p<0.001), N a(p<0.001), M g(p<0.001)$, Tot $N \%$ $(p=0.114), A v P(p<0.001), C a(p<0.001)$ and SAR $(p<0.001) .{ }^{*}$ T0: Tap water; T1: Pure grey water; T2: Mixture of grey water and tap water.

\section{Effect of Irrigation with Grey water on Soil Chemical Properties}

Table 1. Soil chemical properties at harvest.

\begin{tabular}{|c|c|c|c|c|c|c|c|c|}
\hline $\begin{array}{l}\text { TREA } \\
T\end{array}$ & $\mathrm{PH}$ & $\begin{array}{l}\text { EC } \\
(\mu / \mathrm{cm})\end{array}$ & $\begin{array}{l}\mathrm{CA} \\
(\mathrm{mg} / \mathrm{kg})\end{array}$ & $\begin{array}{l}\text { MG } \\
(\mathrm{mg} / \mathrm{kg})\end{array}$ & $\begin{array}{l}\text { Tот N } \\
(\%)\end{array}$ & $\begin{array}{l}\text { Av P } \\
(\mathrm{mg} / \mathrm{kg})\end{array}$ & $\begin{array}{l}\text { NA } \\
(\mathrm{mg} / \mathrm{kg})\end{array}$ & SAR \\
\hline T0 & $6.7 \pm 0.21 \mathrm{~b}$ & $104.2 \pm 6.02 \mathrm{~d}$ & $\begin{array}{l}51.57 \pm 2.34 \\
\text { a }\end{array}$ & $60.96 \pm 0.85 a$ & $\begin{array}{l}0.02 \pm 0.00 \\
1\end{array}$ & $\begin{array}{l}0.54 \pm 0.35 \\
\text { c }\end{array}$ & $\begin{array}{l}0.99 \pm 0.26 \\
\text { c }\end{array}$ & $\begin{array}{l}0.132 \pm 0.003 \\
\mathrm{~d}\end{array}$ \\
\hline $\mathrm{T} 1$ & $7.9 \pm 0.55 \mathrm{a}$ & $\begin{array}{l}358.8 \pm 19.33 \\
\text { a }\end{array}$ & $\begin{array}{l}36.56 \pm 1.08 \\
\text { c }\end{array}$ & $53.98 \pm 1.79 b$ & $\begin{array}{l}0.02 \pm 0.00 \\
5\end{array}$ & $\begin{array}{l}0.94 \pm 0.19 \\
\text { a }\end{array}$ & $\begin{array}{l}3.06 \pm 0.98 \\
\text { a }\end{array}$ & $\begin{array}{l}0.454 \pm 0.061 \\
\text { a }\end{array}$ \\
\hline $\mathrm{T} 2$ & $\begin{array}{l}7.0 \pm 0.60 \mathrm{a} \\
\mathrm{b}\end{array}$ & $\begin{array}{l}287.8 \pm 25.36 \\
\text { b }\end{array}$ & $\begin{array}{l}42.79 \pm 1.53 \\
b\end{array}$ & $\begin{array}{l}56.35 \pm 0.25 \mathrm{a} \\
\mathrm{b}\end{array}$ & $\begin{array}{l}0.02 \pm 0.00 \\
3\end{array}$ & $\begin{array}{l}0.90 \pm 0.19 \\
\text { a }\end{array}$ & $\begin{array}{l}2.89 \pm 0.75 \\
\text { a }\end{array}$ & $0.41 \pm 0.019 b$ \\
\hline $\mathrm{T} 3$ & $6.9 \pm 0.5 \mathrm{ab}$ & $\begin{array}{l}126.0 \pm 9.80 \\
\mathrm{c}\end{array}$ & $\begin{array}{l}43.52 \pm 5.47 \\
b\end{array}$ & $54.31 \pm 0.35 b$ & $\begin{array}{l}0.02 \pm 0.00 \\
4\end{array}$ & $\begin{array}{l}0.65 \pm 0.33 \\
\text { b }\end{array}$ & $\begin{array}{l}2.28 \pm 0.25 \\
\text { b }\end{array}$ & $\begin{array}{l}0.325 \pm 0.006 \\
\text { c }\end{array}$ \\
\hline
\end{tabular}

Mean value \pm Standard deviation (SD); values in column with the different letters are significantly different $(p \leq 0.05)$. $p H(p=0.034), E C(p<0.001), C a(p<0.001), M g(p=0.005)$, Total Nitrogen $(p=$ 0.072), Available $P(p<0.001), N a(p<0.001)$ and SAR $(p<0.001) .{ }^{*}$ T0: soil irrigated with tap water T1: Soil irrigated with pure grey water; T2: Soil irrigated with grey water mixed with tap water; T3: Soil irrigated with an alternation of grey water and tap water.

Table 2. Irrigation induced changes in soil chemical properties.

\begin{tabular}{lcccccccc}
\hline TREAT & PH & EC & CA & MG & TOT N & Av P & NA & SAR \\
\hline T0/Initial soil & 1.0 & 1.0 & 1.5 & 1.2 & 2.0 & 1.1 & 1.1 & 13.2 \\
T1/Initial soil & 1.2 & 3.5 & 1.1 & 1.1 & 2.0 & 1.9 & 3.5 & 45.4 \\
T2/Initial soil & 1.0 & 2.8 & 1.3 & 1.1 & 2.0 & 1.8 & 3.3 & 41.0 \\
T3/Initial soil & 1.0 & 1.2 & 1.3 & 1.1 & 2.0 & 1.3 & 2.6 & 32.5
\end{tabular}

The values in Table 4 represent ratios between measured values for the soil after treatment and before treatment: T0/ Initial soil- values after treatment $\mathrm{T} 0$ divided by value before treatment; T1/ Initial soil - values after treatmentT1 divided by value before treatment; T2/ initial soil - values after treatment T2 divided by value before treatment; T3/Initial soil-values after treatment T3 divided by value before treatment.

Grey water application has significantly affected the measured soil chemical properties except Total $\mathrm{N}$ as was shown in table3. The $\mathrm{pH}, \mathrm{EC}, \mathrm{Av} \mathrm{P}, \mathrm{Na}$ and SAR were significantly 
increased with increase in grey water contrary to $\mathrm{Mg}$ and $\mathrm{Ca}$ concentrations which were significantly decreased with increase in grey water application. Soil irrigated with grey water was found to have the highest value in EC $(358.8 \mu / \mathrm{cm}), \mathrm{Av} \mathrm{P}(0.944 \mathrm{mg} / \mathrm{kg}), \mathrm{Na}(3.06$ $\mathrm{mg} / \mathrm{kg}$ ) and SAR (0.454) which were, respectively, approximately 3.4,1.7, 3.1 and 3.4 times higher than for the soil irrigated with tap water (see table 3). Conversely, grey water irrigated soil had the lowest values in $\mathrm{Ca}(36.56 \mathrm{mg} / \mathrm{kg})$ which was approximately 1.4 times lower than that of the tap water irrigated soil. In relation to the pre-treatment soil, all forms of irrigation water were net suppliers of $\mathrm{Ca}, \mathrm{Mg}, \mathrm{Na}, \mathrm{N}$, and $\mathrm{P}$, and resulted in an increase of SAR (see table 4). The most notable increase in EC, P, Na, and SAR was linked with all forms of irrigation involving grey water.

The results imply that soil alkalinity $(\mathrm{pH})$, salinity (EC) and sodicity (SAR) increased in relation with laundry grey water application. With time, grey water application (T1) tended to increase the soil salinity compared to the same soil irrigated with tap water (T0). On the other hand, alternate irrigation of grey and tap water (T3) significantly mitigated salinisation effect of irrigation with either only grey water or grey water mixed with tap water at 1:1 ratio (T2) (table 3).

Though irrigation with tap water did not result in any significant increase of soil $\mathrm{pH}$ or $\mathrm{EC}$, it resulted in 1.5 times increase of soil $\mathrm{Ca}$ content and almost no $\mathrm{Na}$ increase in the soil. However, irrigation with tap water caused a 13 times increase of SAR, indicating a possible long-term threat to soil quality even by tap water irrigation in such a draughtprone area, i.e., Eastern Rwanda with a very marked long dry season.

The question is then why alternating irrigation using grey water and tap water (T3) did not yield the same result as the use of diluted grey water (1:1 tap- and grey water, T2). Though the amount of tap water used over the experimentation time is the same for both the alternate application of grey water and tap water and the 1:1 grey water/tap water, the resulting mixture of $1: 1$ grey water and tap water retained about $80 \%$ of the salt content of pure grey water while the alternate of grey/ tap water retained only about $35 \%$ of the salt content of pure grey water. Thus, while mixing grey water with tap water reduces soil $\mathrm{EC}$ and $\mathrm{Na}$ content through dilution processes, tap water applied in alternation with grey water is more efficient at flushing salts away through leaching process, hence significantly reducing the accumulation of salts in the upper parts of the soil layers. If that hypothesis is correct, alternate application of tap water and grey water should result in a clearly different accumulation pattern of salts, and more specifically of $\mathrm{Na}$, in the soil profile than that of grey water mixed with tap water. Over a long period of application, a considerable increase of salt concentration in the lower soil levels and possibly in groundwater will be expected due to alternate application of graywater and tap water.

The decrease in $\mathrm{Mg}$ and $\mathrm{Ca}$ concentrations with grey water application is likely to result from sodium in grey water replacing $\mathrm{Ca}^{2+}$ and $\mathrm{Mg}^{2+}$ cations on the soil exchange complex and thus reducing their concentration in the soil solution. If this is the case, monitoring $\mathrm{Ca}$ and $\mathrm{Mg}$ concentration in the soil solution should indicate an initial spike in $\mathrm{Ca}$ and $\mathrm{Mg}$ in the soil solution reflecting their displacement and detachment from the soil exchange complex. Another reason for the drop in the concentrations of $\mathrm{Mg}$ and $\mathrm{Ca}$ in soil solution indicated above is related to soil $\mathrm{pH}$. Because grey water resulted in soil having a $\mathrm{pH}$ above 8.5 , its application to soil reduced gradually the concentration of $\mathrm{Mg}$ and $\mathrm{Ca}$ in the soil solution, possibly accompanied by a translocation of $\mathrm{Ca}$ and $\mathrm{Mg}$ and some clay particles toward lower soil horizons (Miyazawa et al., 2001).

The significant increase in $\mathrm{pH}, \mathrm{EC}$ and SAR induced by irrigation with grey water was similarly reported by Mohammad \& Mazahreh (2003), Anwar (2017), and Pinto et al. (2010). All reported that the application of grey water on soil tended to raise soil alkalinity, salinity and sodicity which reduced the ability of soil to infiltrate, store and convey water to crops. When sodium is the dominant soluble cation in the soil, high $\mathrm{pH}$ 
of the soils results in the precipitation of soluble $\mathrm{Ca}$ and $\mathrm{Mg}$ such that their concentration in the soil solution drops to very low levels causing soil dispersion (Resources, n.d.).

Other researchers such as Al-Jayyousi (2004), Al-Jayyousi (2003) and Al-Hamaiedeh \& Bino (2010) reported that long term irrigation using grey water with SAR greater than 4 will likely disturb the soil properties in such cases, flooding soil or rotating grey water irrigation with fresh water was highly recommended to flush the soil pore spaces and to counteract the accumulation of $\mathrm{Na}$ and heavy metals in the soil.

\section{Effect of Grey water on Soil Physical Properties}

Table 3.Effect of grey water on soil physical properties at harvest.

\begin{tabular}{|c|c|c|c|c|}
\hline TREATMENT & $\begin{array}{l}\text { HYDRAULIC } \\
\text { CONDUCTIVITY } \\
(\mathrm{CM} / \mathrm{SEC})\end{array}$ & $\begin{array}{l}\text { AGGREGATE } \\
\text { STABILITY (\%) }\end{array}$ & BULK DENSITY (G/CM $\left.{ }^{3}\right)$ & POROSITY (\%) \\
\hline T0 & $0.122 \pm 0.01 \mathrm{a}$ & $72 \pm 0.09 a$ & $1.33 \pm 0.001$ & $49.87 \pm 0.05 a$ \\
\hline $\mathrm{T} 1$ & $0.056 \pm 0.01 \mathrm{~b}$ & $57 \pm 0.01 \mathrm{c}$ & $1.50 \pm 0.002$ & $43.37 \pm 0.06 \mathrm{c}$ \\
\hline $\mathrm{T} 2$ & $0.062 \pm 0.02 b$ & $58 \pm 0.06 \mathrm{bc}$ & $1.41 \pm 0.004$ & $46.83 \pm 0.16 b$ \\
\hline $\mathrm{T} 3$ & $0.101 \pm 0.05 \mathrm{a}$ & $61 \pm 0.01 b$ & $1.34 \pm 0.004$ & $49.41 \pm 0.17 \mathrm{a}$ \\
\hline
\end{tabular}

Mean value \pm Standard deviation (SD); means with different letters are significantly different ( $p \leq$ 0.05). Hydraulic conductivity ( $p=0.001)$, Aggregate stability $(p<0.001)$, Bulk density $(p=0.065)$, porosity $(p=0.002)$ * T0: Tap water; T1: Pure grey water; T2: Mixture of grey water and tap water; T3: Alternate irrigation with of grey water and tap water.

Results shown in table 5 illustrated that except soil bulk density, other measured physical properties were significantly reduced with the application of grey water, either in pure form, mixed with tap water or in alternance with tap water. The highest values for soil hydraulic conductivity, aggregate stability and porosity were found for soil irrigated with tap water, which was 2, 1.2, and 1.1 times higher than that of pure grey water, mixed or alternated with tap water, respectively. Though bulk density was not significantly ( $p=$ 0.065 ) affected by the irrigation treatments over the period of the experiment, application of grey water, whether alone or in combination with tap water, resulted in higher bulk densities with the highest density registered for the application of grey water alone.

However, these results showed clearly that soil hydraulic conductivity, aggregate stability and porosity significantly decreased proportionally with the increase in grey water in soil solution. These findings could be explained by the fact that these three physical parameters decrease with soil dispersion which is also increased with decrease in $\mathrm{Ca}$, and to some extent in $\mathrm{Mg}$ concentration. These two elements were reduced in the soil solution reflecting their displacement from the soil exchangeable complex by excess $\mathrm{Na}$ introduced by grey water. These results were in agreements with those found by other researchers such as Magesan et al. (2000) and Abedi-Koupai et al. (2006) who reported a significant decrease in soil physical properties induced by high level of Sodium in grey water.

Recently Shingiro et al. (2020) indicated that application of compost-tea significantly reduced the deleterious effect of urine on soil physical properties such as infiltration and porosity. Several farmers in Rwanda using toilet compost with or without application of urine have indicated the beneficial effect of incorporating sawdust or other source of carbon into composted toilet material (unpublished reports by farmers). This seems to indicate that the application of grey water mixed with compost, compost-tea, aged sow dust or other carbon inputs could be a plausible solution to counterpart the raised issue of grey water on soil physical properties (Shingiro et al., 2020). 


\section{Effect of Grey water on Tomato Growth}

Table 4.Effect of grey water on tomato growth.

\begin{tabular}{llll}
\hline TREATMENT & HEIGHT OF STEM $(\mathrm{CM})$ & WIDTH OF LEAVES $(\mathrm{CM})$ & WEIGHT OF TOMATOES (KG) \\
\hline T0 & $11 \pm 1.765$ & $3.167 \pm 1.041 \mathrm{~b}$ & $4.483 \pm 0.500$ \\
T1 & $11.267 \pm 2.082$ & $3.833 \pm 0.764 \mathrm{a}$ & $4.533 \pm 0.470$ \\
T2 & $11.333 \pm 1.155$ & $3.333 \pm 1.528 \mathrm{~b}$ & $4.500 \pm 0.500$ \\
T3 & $11.333 \pm 2.517$ & $3.167 \pm 0.767 \mathrm{~b}$ & $4.500 \pm 0.030$ \\
\hline
\end{tabular}

Mean value \pm Standard deviation (SD); means with different letters are significantly different $(p \leq 0.05)$. Height of stem $(p=0.904)$, width of leaves $(p=0.028)$, Weight of tomatoes $(p=0.904) . *$ T0: Tap water; T1: Pure grey water; T2: Mixture of grey water and tap water; T3: Alternate of grey water and tap water.

Results from table 6 showed that there was no significant effect on tomato growth. Similarly, the results found from table 6 showed that the application of grey water and tap water didn't significantly affect the stem height and weight of tomatoes; however, it affected significantly only the width of leaves of tomatoes. The highest width of leaves was found in soil irrigated with pure grey water compared to other treatments. Though the increase in stem height and weight of tomatoes was not statistically significant, a slight increase of the two parameters were observed in soil irrigated with pure grey water, mixed or in alternation with tap water compared to that of tap water alone.

This is like the findings reported by Mohammad Rusan et al. (2007) and Misra et al. (2010). They found that tomatoes irrigated with pure grey water had higher nutrient uptake and biomass at the flowering stage when compared to tap water. The higher yields found in these studies were attributed to higher concentration of essential nutrients contained in the grey water compared to control water treatments. Conversely, Al-Zubi \& Al-Mohamadi (2008) reported that where tomatoes were irrigated with grey water there was no increase in yield compared to those irrigated with potable water. Bauder et al. (n.d.), Al-Jayyousi (2003) and Holtzhausen (2005) suggested that caution should be taken when sensitive crops such as pepper, potato and corn are irrigated with grey water that have a high salt concentration because it leads to severe leaf damage and crop failure. Thus, grey water effect on crop yields depends on crop sensitivity.

From a nutrient's perspective, not only was $\mathrm{P}$ the only macro nutrient significantly higher in grey water than of tap water, but $\mathrm{N}$ was also practically absent from grey water, and $\mathrm{Ca}$ and $\mathrm{Mg}$ were significantly lower in grey water than in tap water. Similar results were found by Misra et al. (2010) on their study on the reuse of laundry grey water for irrigation of tomato.

The concentration of $\mathrm{N}, \mathrm{P}, \mathrm{Mg}$ and $\mathrm{Ca}$ in soil are among the factors that influence the quality of tomatoes. $\mathrm{N}$ promotes strong early growth and maximise the flower number of tomatoes, $\mathrm{P}$ maximises root development and boosts fruits development, $\mathrm{Mg}$ improves tomato flowering while $\mathrm{Ca}$ maximises the crop reproductive development and maintains good fruits firmness (Nguyen et al., 2017). However, in the nutrient uptake process $\mathrm{Mg}$ and $\mathrm{Ca}$ are strongly antagonistic (Nguyen et al., 2017; Rietra et al., 2017). The recommended method of applying such highly concentrated grey water on crops was by drip and surface irrigation since this approach allows water to accumulate next to the plant root without direct contact with the leaves (Nguyen et al., 2017). Moreover, salt and boron tolerant plants such as olives and sugar beet should not be a problem if irrigated with salt such as is often found in grey water.

The study by Shingiro et al. (2020) showed that, unlike grey water, urine was much richer in $\mathrm{N}$ and $\mathrm{P}$. The combination of compost tea and human urine maintained soil structure while increasing crop yield, contrary to application of urine alone that increased 
yield only in the presence of abundant fresh water supply. We hypothesise that urine, like grey water, can adversely affect soil structure, soil hydraulic conductivity, and can significantly reduce soil's capacity to supply air and water to crops. Compost tea (using vermicompost) showed great potential to preserve soil aggregation and soil hydraulic properties in soil receiving fertilisation with urine.

\section{Conclusions}

In this study two major research questions were investigated: 1/The effect of grey water on selected soil physico-chemical properties and 2/The effect of grey water on tomato growth. In relation to the first question, grey water was found to increase significantly soil salinity and sodicity. The contribution of $\mathrm{Ca}$ and $\mathrm{Mg}$ in the soil total salt content was also reduced leading to a significant deterioration of physical properties such as porosity, aggregate stability and hydraulic conductivity. Among the macronutrients measured, P was the only significantly supplied by grey water to the soil. Regarding the second question, grey water tended to increase fruit weight as well as leaves' width, though significant increase was only noticed for leaves' width in the case of irrigation with grey water alone.

The most environmentally friendly mode of application of grey water considered in our experiment with regard to soil chemical and physical properties was shown to be its application in alternation with tap water. From a soil physico-chemical perspective, before grey water can be safely reused for irrigation, means to enrich grey water in N, C and $\mathrm{Ca}$ need to be devised, so that grey water becomes bio-chemically active (i.e., promoting soil aggregation) and safe (i.e., without pathogenic agents, biological and chemical toxins). Safely blended grey water, urine, and compost [tea] could hold the key for sustainable reuse of grey water in agriculture.

\section{Acknowledgements}

We appreciate the support of University of Rwanda, College of Agriculture Animal Sciences and Veterinary Medicine. Special thanks go to Solange Uwingabire (lab assistant that assisted in the lab analysis and others) for her assistance and involvement in the accomplishment of this research.

\section{References}

Abedi-Koupai, J., Mostafazadeh-Fard, B., \& Afyuni, M. (2006). Effect of treated wastewater on soil chemical and physical properties in an arid region. Plant Soil Environment, 52(8), 335-344. https://www.agriculturejournals.cz/ publicFiles/50742.pdf

Al-Hamaiedeh, H., \& Bino, M. (2010). Effect of treated grey water reuse in irrigation on soil and plants. Desalination, 256(1-3), 115-119.

Al-Jayyousi, O. (2004). Grey water reuse: knowledge management for sustainability. In Desalination (Vol. 167).

Al-Jayyousi, O. R. (2003). Grey water reuse: towards sustainable water management. Desalination, 156(1-3), 181-192. https://doi.org/10.1016/S0011-9164(03)00340-0

Al-Zubi, Y., \& Al-Mohamadi, F. (2008). Effect of graywater on soil chemical composition and yield of tomato plant. Journal of food, agriculture \& environment 6(2), 408-410.

Anwar, F. (2017). Effect of laundry grey water irrigation on soil properties. Journal of Environmental Research and Development, 5(4), 863-870. https://espace.curtin.edu.au/handle/20.500.11937/49168 
Bandyopadhyay, K., Aggarwal, P., \& Pradhan, S. (2012). Practical Manual on Measurement of Soil Physical Properties. https://www.researchgate.net/ publication/320831062

Bauder, T. A., Waskom, R. M., \& Davis, J. G. (n.d.). Irrigation Water Quality Criteria 0.506 - Extension. https://extension.colostate.edu/topic-areas/agriculture/irrigationwater-quality-criteria-0-506/

Boulware, E. W. B. (n.d.). Water Conservation Strategies in Corrections. Retrieved December 2, 2021, from https://greenprisons.org/gp/m/articles/view/WaterConservation-Strategies-in-Corrections

Eriksson, E., Auffarth, K., Henze, M., \& Ledin, A. (2002). Characteristics of grey wastewater. Urban Water, 4(1), 85-104. https://doi.org/10.1016/S14620758(01)00064-4

Erwin, N. (2005). Grey water recycling systems in Germany - Results, experiences and guidelines. Water Science \& Technology. https://doi.org/DOI: 10.2166/ wst. 2005.0368

Food and Agriculture Organization. (2019). New project to strengthen Rwanda's water governance, adaptation to climate change. https://www.fao.org/ rwanda/news/detail-events/en/c/1207595/

Holtzhausen, L. (2005). From Grey to Green: Reusing Wastewater for Food. In The Water Wheel (pp. 10-12). https://journals.co.za/doi/pdf/10.10520/EJC115527

IFDC. (2014). Rwanda Fertilizer Assessment In Support of The African Fertilizer and Agribusiness Partnership. www.ifdc.org

Kayonza District. (n.d). Republic of Rwanda Eastern Province Kayonza District Kayonza District Developpement Plan.

Magesan, G. N., Williamson, J. C., \& Yeates, G. W. (2000). Wastewater C:N ratio effects on soil hydraulic conductivity and potential mechanisms for recovery. https://agris.fao.org/agris-search/search.do?recordID=US201600117468

Matto, M., \& Jainer, S. (2019). Potential of Rainwater Harvesting in Rwanda. A deepdive into Best Management Practices of Rainwater Harvesting Systems in Kigali.

Misra, R. K., Patel, J. H., \& Baxi, V. R. (2010). Reuse potential of laundry grey water for irrigation based on growth, water and nutrient use of tomato. Journal of Hydrology 386(1-4), 95-102.

Miyazawa, M., Pavan, M. A., Ziglio, C. O., \& Franchini, J. C. (2001). Reduction of exchangeable Calcium and Magnesium in soil with increasing pH. Brazilian Archives of Biology and Technology, 44(2), 149-153.

Mohammad, M. J., \& Mazahreh, N. (2003). Changes in soil fertility parameters in response to irrigation of forage crops with secondary treated wastewater. Communications in Soil Science and Plant Analysis, 34(9-10), 1281-1294. https://doi.org/10.1081/CSS-120020444

Mohammad Rusan, M. J., Hinnawi, S., \& Rousan, L. (2007). Long term effect of wastewater irrigation of forage crops on soil and plant quality parameters. Desalination, 215(1-3), 143-152. https://doi.org/10.1016/J.DESAL.2006.10.032

Nguyen, H. H., Maneepong, S., \& Suraninpong, P. (2017). Effects of Potassium, Calcium, and Magnesium Ratios in Soil on Their Uptake and Fruit Quality of Pummelo. Journal of Agricultural Science, 9(12), p110-p110. https://doi.org/ 10.5539/JAS.V9N12P110

Okalebo, G. \& W. (2002). Laboratory methods of soil and plant analysis: a working manual. In Researchgate.Net.

Pescod, M. (1992). Wastewater treatment and use in agriculture - FAO irrigation and drainage paper 47. Undefined. 
Pinto, U., Maheshwari, B. L., \& Grewal, H. S. (2010). Effects of grey water irrigation on plant growth, water use and soil properties. Resources, Conservation and Recycling, 54(7), 429-435. https://doi.org/10.1016/J.RESCONREC.2009.09.007

Resources, D. of A. and N. (n.d.). Soil salinity and sodicity effects on chemical properties - Salinity Management. https://ucanr.edu/sites/Salinity/Salinity_Management/ Effect_of_salinity_on_soil_properties/Soil_salinity_effect_chemical_properties/

Rietra, R. P. J. J., Heinen, M., Dimkpa, C. O., \& Bindraban, P. S. (2017). Effects of Nutrient Antagonism and Synergism on Yield and Fertilizer Use Efficiency. Communications in Soil Science and Plant Analysis, 48(16). https://doi.org/10.1080/00103624.2017.1407429

Sheikh, B., Nelson, K. L., Haddad, B., \& Thebo, A. (2018). Grey Water: Agricultural Use of Reclaimed Water in California. Journal of Contemporary Water Research \& Education, 165(1), 28-41. https://doi.org/10.1111/j.1936-704x.2018.03291.x

Shingiro, C., Nyagatare, G., Hirwa, H., \& Uwingabire, S. (2020). Effect of human urine and compost tea as fertilizers for maize, beans and cabbage production in Rwanda, Rubirizi marshland. International Journal of Plant Science and Ecology, 6(1), 1-6. http://www.publicscienceframework.org/journal/paperInfo/ijpse?paperId=4745

World Bank Group. (2021). Rwanda climate risk country profile. www.worldbank.org

World Health Organization. (2006a). Guidelines for the safe use of wastewater, excreta, and grey water. World Health Organization. https://apps.who.int/ iris/handle/10665/116516

World Health Organization. (2006b). Overview of grey water management health considerations. https://apps.who.int/iris/handle/10665/116516 